\title{
Ambivalence About Equality in the United States or, Did Tocqueville Get it Wrong and Why Does that Matter?
}

\section{Citation}

Hochschild, Jennifer L. 2006. Ambivalence about equality in the United States or, did Tocqueville get it wrong and why does that matter? Social Justice Research 19(1): 43-62.

\section{Published Version}

http://dx.doi.org/10.1007/s11211-006-9999-2

\section{Permanent link}

http://nrs.harvard.edu/urn-3:HUL.InstRepos:3425915

\section{Terms of Use}

This article was downloaded from Harvard University's DASH repository, and is made available under the terms and conditions applicable to Other Posted Material, as set forth at http:// nrs.harvard.edu/urn-3:HUL.InstRepos:dash.current.terms-of-use\#LAA

\section{Share Your Story}

The Harvard community has made this article openly available.

Please share how this access benefits you. Submit a story.

Accessibility 


\title{
Ambivalence about Equality in the United States,
}

\author{
Or, \\ Did Tocqueville Get It Wrong and Why Does That Matter? \\ Jennifer L. Hochschild ${ }^{1}$
}

Paper prepared for special issue on "Interrupting Oppression and Sustaining Justice," Social Justice Research

Running head: "Ambivalence about Equality in the U. S.”

Mailing address: Harvard University

Government Department

Littauer Center, North Harvard Yard

Cambridge MA 02138

Hochschild@1atte.harvard.edu

617-496-0181

\begin{abstract}
Alexis de Tocqueville believed that ““'democratic peoples'... passion for equality is ardent, insatiable, eternal, and invincible." This article examines whether and under what conditions residents of the United States demonstrate such a commitment to equality. I show that at many points in history, Americans have indeed chosen to move toward greater justice and less oppression; however, there are clear limits to their passion for equality. White Americans endorse less social, political, and economic equality than do African Americans, but even the latter often resist equality for groups that they perceive to be threats or for behaviors that threaten strong social or moral norms. The article discusses implications for political activists of these patterns of support for and resistance to greater equality, and suggests strategies for overcoming oppression and promoting justice.
\end{abstract}

KEY WORDS: equality, de Tocqueville, public opinion surveys, race, group boundaries, redistribution, social norms

\footnotetext{
${ }^{1}$ Henry LaBarre Jayne Professor of Government and Professor of African and African American Studies, Harvard University, Cambridge MA 02138
} 
In a chapter of Democracy in America explaining "why democratic nations show a more ardent and enduring love for equality than for liberty," Alexis de Tocqueville argued in 1848 that the "passion for equality is daily acquiring a greater hold over the human heart.... The particular and predominating fact peculiar to those [i.e. "democratic"] ages is equality of conditions, and the chief passion which stirs men at such times is the love of this same equality." A few paragraphs later he adds, "democratic peoples'... passion for equality is ardent, insatiable, eternal, and invincible. They want equality in freedom, and if they cannot have that, they still want equality in slavery" ((de Tocqueville 1966 (1848)): 473-476).

In recent decades, Tocqueville has acquired the status of sage, with a standing similar to that of Thomas Jefferson or Benjamin Franklin. Nevertheless, I argue in this article that in this passage he was wrong, or at least not fully right. Americans find it, in fact, very difficult to sustain their dedication to equality when it is defined as anything more robust than a thin equality of opportunity synonymous with liberty (for various meanings of equality, see (Rae et al. 1981)). I do not assert, in direct opposition to Tocqueville, that residents of the United States always choose liberty over a thick understanding of equality; that claim is demonstrably false for crucial periods of U.S. history. But even those segments of the population most committed to equality or most in need of efforts to promote it -- African Americans and Latinos - find it hard to maintain their commitment in certain circumstances. European Americans on average are much more ready to sacrifice equality to some other value or to perceive it as irrelevant in many situations, and Asian Americans are probably more like Anglos than like other nonAnglos.

To make this argument in a brief compass, I rely primarily on survey data -- not because they are always true or trustworthy, but because they provide a quick way to make an empirical argument that then warrants investigation through more historical or qualitative methods. Survey data also remind activists and scholars that many residents of the United States hold values and perspectives different from our own. Their views must be taken seriously, on their own terms, if we are ever to reduce injustice in this or any other nation.

As that sentence suggests, I approach the issue of "interrupting oppression" through Tocqueville's pronouncement for two reasons. First, a political strategist needs a clear sense of the terrain ahead; how members of the public understand the idea of equality and evaluate policies to promote it is an essential part of that terrain. After all, political strategies in the electoral, protest, and institutional arenas will all differ considerably depending on whether advocates have strong and wide public backing, narrow and deep public backing, or shallow and wayward public backing; they had better know where they stand. Second, seeing where and how residents of the United States do support greater equality can give some help in deciding where to focus political resources. No smart political actor will simply follow public opinion (even if he or she agrees that surveys accurately represent it). But if one can perceive patterns of support, 
hesitation, or opposition to specific issues or framings, one is better able to conceive of appropriate coalitions and promising policy foci. Such, at any rate, is my hope - and in the conclusion I suggest implications of this analysis for political organizing to interrupt oppression.

This paper roughly equates support for equality with a move toward greater justice. That, of course, is contestable; analysis of the meanings of equality or justice, and of the relationships between the two, can take up volumes (it has done so many times; see, for example, (Schaar 1964); (Nozick 1974); (Hochschild 1981); (Pateman 1988); (Pole 1993); (Mills 1997); (Rawls 1999)). Here I simply assert that an expansive understanding of equality of opportunity - in which all individuals have a reasonably similar and wide array of real choices about how to live their lives ((Rae 1988)) - is a necessary condition for justice in a wealthy, western society such as the United States.

\section{Commitment to Equality in the United States}

Let us start by noting crucial moments in which the nation's dedication to equality - or perhaps, the dedication of enough members of the nation to outweigh opponentsprevailed. These are moments in which particular sorts of oppression were indeed interrupted, sometimes permanently. They include:

- the prohibition of laws of primogeniture in the Constitution;

- separation of church and state in the first amendment, giving people of all religious convictions, or none, equal political standing;

- decisions in state constitutional conventions of the 1820 s and 1830 s to open the franchise to propertyless white men;

- the Civil War, and the institutionalization of its outcome in the $13^{\text {th }}, 14^{\text {th }}$, and $15^{\text {th }}$ amendments to the Constitution;

- policies in the nineteenth century that established the principle and sometimes the practice of tax-supported public schools for all (nonenslaved) children;

- the $16^{\text {th }}$ Amendment that permitted a progressive individual income tax;

- the $19^{\text {th }}$ Amendment that granted the franchise to women;

- laws and policies of the New Deal, especially with regard to social security, that provided the foundation for a nation-wide social welfare state;

- laws and policies of the New Deal, especially with regard to the right to unionize, that gave workers countervailing leverage against employers;

- the McCarran-Walter Act of 1952 that permitted all legal immigrants to become naturalized citizens;

- the $24^{\text {th }}$ Amendment that abolished the poll tax;

- the $26^{\text {th }}$ Amendment that lowered the age of voting to 18 ;

- the Hart-Celler immigration law of 1965 that eliminated national quotas for immigrants;

- court decisions and civil rights laws of the 1950s-1970s that abolished statesupported segregation and granted formal political equality to all adult citizens regardless of race, national origin, or gender;

- court decisions and laws of the 1960s-1990s that required states and school districts to provide students with disabilities a "free and appropriate public education" in the "least restrictive environment;" and 
- court decisions at the federal and state levels since 2000 that decriminalized consensual homosexual behavior and are perhaps opening the door to legal marriage between same-sex couples.

One could add others, but that is a rather compelling list and should hearten those committed to sustaining justice. With one glaring exception, in each case a majority of the enfranchised population chose to peacefully permit their own power, status, or level of resources to be diminished for the sake of enhancing the standing of those with little or no political clout. The exception, of course, was the Civil War, in which probably most Union soldiers fought and died to preserve the union rather than to free slaves. Even in that case, however, many northerners were moving toward an abhorrence of slavery by the end of the war ((McPherson 1997)), and the three post-war amendments were ratified democratically. So a majority of people in the United States have in fact frequently behaved as though they held "an ardent and enduring love for equality" over the past several hundred years, even if more slowly, partially, and grudgingly than their fellow residents deserved.

It is trivially easy to find evidence that people in the United States overwhelmingly endorse the principles of political and social equality, as well as equality of opportunity for education, job advancement, or upward mobility in general ((Hochschild 1995): 55-56). ${ }^{2}$ Survey respondents sometimes even seem to believe that they live in a reasonably egalitarian society. In the early 1990s, less than a fifth saw race, gender, religion, or class as very important for "getting ahead in life." Even two-thirds of the poor were certain that people like themselves "have a good chance of improving our standard of living," and up to three times as many residents of the United States as Europeans make that claim ((Hochschild 1995): 19, see also 21-23, 56-57).

At other times, they are not so certain. In 2002, fully three-fifths rejected the bald statement that "the economic and political systems in the country offer equal opportunities for everyone" ((NBC News/ Wall Street Journal 2002)); a few months later, three-fifths also agreed that our nation is not close to "eliminating discrimination against racial and ethnic minorities in America once and for all" ((Associated Press 2003)). Nevertheless, two-thirds still believe that "race relations in this country will ... [someday] get better than they are" now ((Time, C.N.N. and Harris Interactive 2003)). Clearly people are conflicted about the actual degree of equality in the United States' society and polity, and therefore about the amount and urgency of political action needed to generate more of it.

\section{Racial Differences in Aspirations for Equality}

Although virtually all residents of the United States endorse the principle of equality, defined variously, racial and ethnic differences nevertheless exist in the relative

${ }^{2}$ To give only one example, for all respondents in the American National Election Study (ANES) from 1982 through 2000, 87 percent of Anglos, 94 percent of blacks, and 91 percent of both Hispanics and Asians agreed that society should ensure equal opportunity for its members (analyses of survey data by author, unless otherwise noted). 
commitment to equality as compared with liberty. ${ }^{3}$ Higher proportions of Latinos and much higher proportions of African Americans than of Anglos identify with and vote for the Democratic party, the party which, roughly speaking, has placed a higher value on substantive equality over the past few decades. From 1972 on, the American National Election Study (ANES) has given its respondents a thermometer scale, in which they are asked their "warmth" toward a particular object. Averaging across the three decades, and with the scale set at 0 for complete neutrality, whites rated Democrats at -2.1 , Hispanics rated Democrats at 4.2, and blacks rated the party at 8.8. ${ }^{4}$ More African Americans than Anglos or Latinos call themselves liberal (rather than moderate or conservative) - again a rough indicator of placing a higher value on substantive equality. ${ }^{5}$ And on most policy issues involving downward redistribution of resources or status, non-Anglos are closer to Tocqueville's model than are Anglos. Let us consider a few such issues.

Social Welfare Policy: On virtually every social welfare policy preference ever measured, many more African Americans and somewhat more Hispanics than European Americans make the downwardly redistributive choice ((Hamilton and Hamilton 1997)). For example, looking only at the ANES from 1972 to 2000:

- 60 percent of blacks, 55 percent of Latinos, and 41 percent of Anglos endorsed federally-funded rather than privately-funded health insurance;

- 60 percent of blacks, 45 percent of Latinos, and 24 percent of Anglos endorsed federal assistance to "ensure that every person has a job and a good standard of living;"

- two-thirds of blacks, just over half of Latinos, and one-third of Anglos endorsed more government spending in order "to provide many more services... in areas such as health and education;"

- four-fifths of blacks, two-thirds of Latinos, and half of Anglos supported more federal spending on social security; and

- about four-fifths of blacks and Latinos, and three-fifths of Anglos endorsed more federal support for public schooling.

These findings could be multiplied many times over on the General Social Survey (GSS) or any reputable national survey. Tocqueville's image of a population with "an ardent

${ }^{3}$ In almost all surveys, there are too few Asian Americans to be analyzed. Thus this paper concentrates on Anglos, African Americans, and Latinos, but by default rather than by choice.

${ }^{4}$ In the ANES from 1972-2000, over 80 percent of blacks, 63 percent of Latinos, and 46 percent of Anglos identified as Democrats. Similarly, 92 percent of blacks, 63 percent of Latinos, and 40 percent of Anglos voted for Democratic presidential candidates. In both cases, the results did not materially differ by decade.

${ }^{5}$ For ANES respondents from 1972 through 2000, 38 percent of blacks, 24 percent of Latinos, and 23 percent of Anglos identified as liberals. The proportion of Anglos who called themselves liberal did not materially differ by decade; the proportion of liberal Latinos dropped in the 1990s, and the proportion of liberal blacks dropped from the 1970 s to the 1980 s. 
and enduring love for equality" holds at the level of concrete policy choices more for blacks and Hispanics than for European Americans.

Race Policy: It is no surprise that African Americans are equally or even more passionate about racial equality than about downward redistribution of resources, and much more passionate about racial equality than are European Americans. Latinos, as before, fall between the two polar groups. Again using the 1972-2000 ANES to represent a vast array of surveys, we see that:

- on a thermometer scale normed at 0 , whites rated civil rights leaders at -16.5 , Latinos at -0.7 , and blacks at 7.8 (this question was not asked in the 1990s);

- on the same scale, whites rated Jesse Jackson at -18 , Latinos at -6.4 , and blacks at 7.6 (this question was not asked in the 1970s);

- half of Anglos, a third of Latinos, but only a quarter of blacks agreed that there has been "a lot" of "real change... in the position of black people in the past few years;"

- three-fifths of blacks, two-fifths of Latinos, and one fifth of Anglos agreed that the federal government "should make every effort to improve the social and economic position of blacks;"

- 84 percent of blacks, 71 percent of Latinos, and 38 percent of Anglos agreed that the federal government should ensure that schools are integrated; and

- in the 1980s and 1990s, two-thirds of blacks, compared with just over one-third of Latinos and Anglos disagreed that civil rights leaders have "pushed too far."

The same pattern holds for support for affirmative action and all other policies that can plausibly be understood to promote racial equality: strong majorities of African Americans endorse them, the proportion of supportive Anglos varies from a small to a substantial minority, and Hispanics are in between. In the arena of racial equality, in short, the evidence does not warrant an image of a population with an ardent and enduring love of equality -- but it does show something close to that among African Americans and, to a lesser degree, Latinos.

\section{White Ambivalence about Equality}

I have shown to this point that Anglos are not passionately committed to equality above liberty or all other values, and are generally less committed to equality than are nonAnglos. But I have not yet specified the nature of their mixed feelings. Most European Americans do now agree, as they did not half a century ago, that all people have a right to the same social and political standing regardless of their background, wealth, race, immigration status, or gender; thus they now endorse something close to Tocqueville's equality of conditions or Jefferson's assertion that all men are created equal (for the historical background of this change, see (Smith 1997)). Nevertheless, many Anglos remain strongly opposed to policies or practices that many nonwhites see as essential for promoting greater racial equality, more downward redistribution of resources, or both. Thus by "white ambivalence about equality," I mean whites' simultaneous endorsement of the norm of equality and rejection of some steps that could promote it. Consider a few examples.

School Desegregation: If we can believe polls, most residents of the United States accept the values underlying school desegregation. By 1995, fully 96 percent of whites agreed that black and white children should attend the same rather than separate schools (up 
from half in 1956). Similarly, only 12 percent of whites claimed in 1997 that they would object if half of the children in their own child's school were black, down from 47 percent in 1958 ((Schuman et al. 1997): 103-110, 240-241; (Gallup Organization 1997); (Davis, Smith and Marsden 2001): q. 133A-B; see also (Hochschild 1984): 179-187).

Less well known is the fact that most people in the United States also believe that school desegregation has, on balance, worked. Up to two-thirds of both blacks and whites now agree that integration has "improved the quality of education received by black students." The younger the respondents, the more likely they are to have had experience with desegregation and the more likely they are to agree. ${ }^{6}$ Up to half of Americans also agree that integration "improved the quality of education received by white students," and that number also has slowly but steadily risen through the 1990s. Here too, the younger the respondents, the more positive they were. (By 1999, 70 percent of young adults but only 45 percent of the elderly believed that whites' education had improved as a result of school desegregation.) On this question, however, the races split; a majority of blacks but a minority of whites agreed throughout the 1990s that desegregation helped white students. ${ }^{7}$

Finally, two-thirds of those surveyed agreed by the mid-1990s that school desegregation has "improved relations between blacks and whites." More blacks than whites-74 to 62 percent--hold this view, but that is still a solid majority of whites. Respondents under age 50 are more likely to agree than those over 50 . These results again mark a big shift; in 1971, only two-fifths of all respondents thought desegregation had improved race relations, and almost as many thought it had "worked against better relations" ((Charles F. Kettering Foundation 1971); (Elam 1989): 30; (CNN/ U.S.A. Today 1994)).

And yet, despite their egalitarian principles and fairly sanguine view of the effects of desegregation, a lot of people hang back when it comes to putting their views into practice. Whites' support for federal government intervention to "see to it that black and white children are allowed to go to the same schools" peaked at 48 percent in 1966 and declined to 25 percent by 1994 . At most a third of whites support busing to achieve racial balance, up from roughly a tenth in the early 1970s. Even questions stipulating that the amount of busing would not increase with mandatory desegregation gain support from fewer than a fifth of white Americans ((Schuman et al. 1997): 123-130 and updates at http://tigger.cc.uic.edu/ krysan/t32.htm; (Davis 1997); (Harris 1970); (NAACP Legal Defense and Educational Fund 1989): 24-25).

There are a lot of good reasons to be wary of mandatory busing, so opposition to it does not necessarily imply opposition to the equalizing policy of desegregation. This is

6 In 1999, 80 percent of young adults and 63 percent of the elderly thought desegregation had helped blacks' education ((CNN/ U.S.A. Today 1999)). In 1971, only 42 percent of all Americans agreed (Charles F. Kettering Foundation 1971); results not available by race). For intervening years, see (CNN/ U.S.A. Today 1994); Phi Delta Kappa 1988 and 1996.

${ }^{7}$ See citations in note 6 . For both questions, there are no clear patterns by region; those with less education were more likely to see gains for whites than were those with more education. One would not have predicted either result in 1975. 
not the place to debate the merits of busing, or even school desegregation; my point is that whites in the United States -- and increasingly on this issue, U.S. blacks - are deeply ambivalent about taking the step that would most directly satisfy the principle of equal opportunity in schooling. Most pointedly, while few Anglos endorse busing to desegregate schools, few have supported any other mandatory state actions to accomplish it either. In a 1972 survey, for example, only 20 percent were willing to "create more housing for low income people in middle income neighborhoods," and about 30 percent were willing to consider redrawing school district boundaries. The rest split roughly evenly among those who favored "do[ing] something other than" those proposals, those opposed to school desegregation, and those with no answer at all ((Gallup Organization 1973); see also (Gallup Organization 1975); (Harris 1978)).

It is unlikely that these solutions are any more popular today. Whites in the United States endorse school desegregation in principle, and believe that it has benefited blacks, the nation as a whole, and at least some members of their own race. They support voluntary measures to achieve it but nothing more, despite clear evidence that voluntary measures lead to very little actual increase in integrated schooling. As one observer put it recently, "today a bipartisan consensus holds that integrated schools are a good thing but we shouldn't do much of anything to promote them" ((Kahlenberg 2001): 42). Reparations: This is a new issue for most people in the United States, although an old concern within the African American community. Views are not settled on it. Nevertheless, it too shows a sharp disparity between general principles and support for possible policies to implement them, especially among whites. Virtually all Anglo Americans agree that enslavement was wrong. But only 30 percent, compared with 79 percent of blacks, agree that the federal government should "apologize to African Americans for the slavery that existed in this country." Similarly, two-thirds of blacks, but only a meager 4 percent of whites, believe that the federal government should "pay monetary compensation to African Americans whose ancestors were slaves" ((Dawson and Popoff 2004): figures 4, 5. For similar results on apology, see (Newsweek 1997); and on reparations see (Fox News 2001)).

One may oppose financial reparations for many reasons other than resistance to egalitarianism. But these racial gaps are vast, and it is especially difficult to justify a refusal to apologize for something that one has acknowledged to be very wrong. An apology would have no immediate impact on interrupting economic oppression -although it would give a boost to lawsuits seeking reparations -- but it would help in promoting the social or psychological equality of conditions that Tocqueville found so striking among (white) citizens of the United States. Nevertheless, seven in ten whites do not support such a step.

Criminal Justice System: Virtually all people in the United States endorse the principles of racial fairness in the criminal justice system and "innocent until proven guilty" in encounters with the law. They also concur on the need for an effective system of criminal justice. African Americans have arguably the greatest commitment to a strong system because they perceive more crime and fear it more than do members of other groups. In 2003, for example, 84 percent of blacks, compared with 57 percent of whites, agreed (incorrectly) that there is "more crime in the U.S. than there was a year ago" ((Bureau of Justice Statistics 2004): table 2.32). In 2003 also, over six in ten whites, compared with five in ten Hispanics and only four in ten blacks were "very satisfied" 
with their "safety from physical harm or violence" ((Gallup Organization 2003)). In all 19 years that the question has been asked (by GSS) since 1973, more nonwhites than whites agree that there is an area near their home where they are "afraid to walk alone at night" (BJS, 2004: table 2.36; see also (Johnson 2002): table A3).

Nor are blacks less punitive than whites about appropriate punishment for many crimes. In 2001, surveyors found no difference between black and white responses to the question of whether "too many people are put in jail just for possessing drugs." More Latinos, however, disagreed ((Bureau of Justice Statistics 2001): table 2.49). ${ }^{8}$ In 11 of the 13 years that the question has been asked (by GSS) since 1985, more blacks than whites have agreed that the nation spends too little money on "halting the rising crime rate" (BJS, 2004: table 2.41). This is not a portrait of a population soft on crime.

Shared support for a strong criminal justice system does not, however, translate into shared satisfaction with the one that exists. For example, fewer than half as many Anglos (16 percent) as Hispanics and African Americans (about 40 percent of both) report being "sometimes afraid" that "the police will stop and arrest you when you are completely innocent" (BJS, 2004: table 2.25). Perhaps more disconcerting is the fact that many Anglos perceive no racial or ethnic bias in the system, so that they insulate themselves from difficult questions of how to eliminate it. Twice as many blacks and Latinos (56 percent of both) as European Americans (27 percent) agree that the police in their community treat one or more racial groups unfairly (BJS, 2004: table 2.24). Among eight items on another recent survey, the gap between the proportion of African Americans and whites who perceived racial bias in the administration of justice ranged from 27 to 57 percentage points ((Johnson 2002): table 1; see also (Hurwitz and Peffley 2001); (Wortley, Hagan and Macmillan 1997)). Most persuasively, asked simply whether "the opportunity for equal justice under the law is equal for blacks and whites," half of whites, compared with a third of Latinos and only a seventh of blacks, said yes. (Asked the same question, but this time comparing Hispanics and whites, half of whites, just over a third of Latinos, and just over a fifth of blacks concurred.) Almost a third of Anglos, a quarter of Hispanics, but only a tenth of blacks agreed that "the opportunity for fair treatment by the police is equal for blacks and whites" ((National Conference for Community and Justice 2000)). Over a third of whites, over a quarter of Latinos, and only a seventh of blacks concurred that Hispanics and whites have the opportunity for fair treatment by the police. In short, blacks and whites are not viewing the same world here; Latinos are in between but closer to African Americans.

As with the other policy arenas I have considered, there are reasons apart from a commitment to equality or justice why Anglos might see less injustice in the criminal justice system or feel less urgency about correcting the injustice that they do see. But that is just the point. Since every political issue that can plausibly be framed as a matter of justice can also be understood in some other way, there are many ways to avoid policies that might actually equalize while simultaneously espousing equalizing principles. Americans frequently avail themselves of those alternative understandings (for more

\footnotetext{
${ }^{8}$ About half of both white and black respondents disagreed, compared with three-fifths of Latinos. In all surveys, Anglos endorse capital punishment for murder more than do blacks (and usually Hispanics).
} 
detail on how, see (Hochschild and Herk 1990); Rae et al., 1981). To do so may not always be wrong, but it does suggest the degree to which Tocqueville was mistaken; residents of the United States, perhaps especially European Americans, often eschew equality in favor of some other value. To the degree that that is true, oppression may continue and justice be constrained.

\section{Black Ambivalence about Equality}

It is perhaps surprising, given what I have written so far, to find that African Americans are sometimes also ambivalent about equality. Such circumstances are rarer, but identifying them enables us to see just where Tocqueville is not a good guide on Americans' priority of equality over liberty or other values. Blacks' uncertainty about equality mainly involves claims that appear to challenge their racial goals, especially when it looks as though another group will obtain too many advantages that African Americans have struggled for and still perceive a dire need for. The obtruding group is typically (white) women, Latinos, Asians, or immigrants. The policies that seem most vulnerable are affirmative action, jobs, and social welfare benefits. When faced with a potentially threatening group and/or policy change, African Americans' ardent and enduring love for equality bumps up against their anxiety about being, once again as so often in U.S. history, left at the bottom of the heap.

That, in any case, is how I interpret survey results such as the following:

- in the 1984 National Black Election Study (NBES), two-thirds agreed that new immigrants "are taking jobs away from black people;"

- in the 1993-94 Black Politics Study (BPS), over half agreed that new minorities could be effective political allies for African Americans. But 70 percent also agreed that "jobs should go first" to unemployed blacks and other Americans in economic distress, rather than allowing new immigrants to "have an equal chance at jobs;"

- in the 1994 GSS, blacks were not distinctively hostile to immigration or fearful of the effects of immigrants on the nation. Nevertheless, a higher proportion of blacks than whites disagreed that legal immigrants should be immediately eligible for social welfare services, and a higher proportion agreed that immigrants are "too demanding in their push for equal rights;"

- in the 1996 NBES, 81 percent agreed that immigrants should have to wait a year or more before being eligible for welfare; 49 percent endorsed a limit to immigration and only 9 percent supported an increase;

- in the 1996 GSS, as many blacks as whites (a third of each) agreed that "foreigners should not be allowed to buy land in America;"

- in 1994, well over half of black voters in California supported Proposition 187, which proposed that illegal immigrants be denied public services such as schools and hospitals. ${ }^{9}$

${ }^{9}$ More than 60 percent of Anglo voters, almost 60 percent of Asian American voters, and about 30 percent of Latino voters also supported the proposition. 
- almost as many blacks as whites in New Jersey ( $38 \%$ compared with $42 \%)$ agreed at the end of September 2001 that airport security personnel should treat Middle Eastern travelers with "more suspicion" than others ((Jennelle 2001));

- slightly fewer blacks endorse a federal apology to Asian Americans for the internment camps of World War II than endorse an apology to blacks for slavery; more whites support an apology to Asians than to blacks ((Dawson and Popoff 2004): figures 2, 4);

- considerably fewer blacks support federal compensation to Asian Americans for internment camps than support compensation to blacks for slavery; in contrast, whites are more likely to endorse compensation to Asians than to blacks ((Dawson and Popoff 2004): figures 3,5);

- in the 1994-2000 GSSs, 34 percent of blacks strongly endorsed affirmative action for African Americans, while fewer (29 percent) said the same about women. To put the same point a different way, among the 34 percent of African Americans who strongly supported affirmative action for blacks, only 30 percent strongly endorsed the same policy for women. ${ }^{10}$

African Americans are also sometimes more socially or morally conservative than Anglos, and more socially and morally conservative than one would expect if economic egalitarianism paralleled liberal social views. Conservatism of this sort generally cuts against support for equality with regard to roles or opportunities. Thus:

- in the 1972-2000 ANES, although a majority of respondents of all groups say yes, blacks fall between Anglos and Latinos in their degree of enthusiasm for whether "women should have an equal role with men in running business, industry, and government;"

- in the 1972-2000 GSS, 44 percent of Anglos, but only about 30 percent of blacks and Latinos are clearly pro-choice with regard to abortion policy (see also BJS, 2004: table 2.101);

- in the 1972-2000 GSS, 74 percent of blacks, compared with about 57 percent of both Latinos and Anglos disapproved of a Supreme Court ruling forbidding prayer in public schools;

- in the same series, about a third of all groups, but a slightly higher percentage of blacks, held a conservative view in a 5 item index of appropriate sexual behavior;

- in the same series, 41 percent of blacks, compared with 38 percent of Latinos and 32 percent of Anglos held conservative views on a variety of free speech rights (see also Jost et al. 2003);

- in 2004, 55 percent of whites but only 36 percent of blacks agreed that "homosexual relations between consenting adults should be legal" (BJS, 2004: table 2.99);

${ }^{10}$ Women returned the compliment; 22 percent strongly endorsed affirmative action for women, but only 11 percent said the same for blacks. Among those women who strongly supported affirmative action for women, only 22 percent held the same view about affirmative action for African Americans. (This implies that support of affirmative action for women and blacks is very largely uncorrelated) 
- unlike in the 1970s, by the mid-1980s and continuing to the present, more whites than nonwhites believe that the use of marijuana should be legalized (BJS, 2004: table 2,67); and

- in the 1996 NBES, 51 percent of blacks endorsed a family cap for welfare recipients and 68 percent supported a 5-year limit on lifetime recipiency of welfare benefits.

Even African Americans, in short, have mixed views of equality when it is applied to certain groups of people, policy issues, or social roles and moral precepts. While their commitment to economic, racial, and political egalitarianism is consistently greater than that of whites, there remains a pattern of important exceptions to it. Advocates of social justice, at least if they define justice as greater and more equal opportunities in all arenas for all residents of the United States, must take into account the fact that a substantial number of black Americans will not be their natural allies.

\section{Evaluating Tocqueville's Dread}

As Tocqueville saw it, "the gradual progress of equality is something fated.... It is universal and permanent, it is daily passing beyond human control, and every event and every man helps it along." All of Democracy in America, he informs the reader, "has been written under the impulse of a kind of religious dread inspired by contemplation of this irresistible revolution advancing century by century over every obstacle." How should we evaluate this intensely powerful image? Can we believe that the end of those forms of oppression that are caused by inequality is just a matter of time in the United States, or at least that historical momentum is on our side?

Arguably, over the long view Tocqueville identified the right central tendency. As I noted at the beginning of this article, with one crucial exception residents of the United States have over the past two centuries used peaceful and democratic means to make the nation's polity, society, and economy more equal. The exception of the Civil War required hitherto-unheard-of violence to overcome the most egregious and structurally embedded inequality, racially-based slavery. However, it too largely succeeded - mostly only formally for a century, but with real consequence in the last few decades. People who engage in politics in the United States have not always chosen the more egalitarian route, they have reversed course more than once, some injustices remain ignored, and new injustices arise. Nevertheless, at significant points, Americans have chosen equality, even at a noticeable cost to politically powerful or economically and socially advantaged actors.

But Tocqueville's dread of Americans' "ardent, insatiable, eternal, and invincible passion... for equality" seems overblown even for a book that the author was seeking to turn into a bestseller. The United States has done less over the past half century to redistribute wealth downward than virtually all other comparable nations, and resource differences between the affluent and poor are high and growing ((Rainwater and Smeeding 2003)). The United States has a vastly higher rate of incarceration than do comparable nations, and the disfranchisement of ex-felons has clear political impact ((Manza and Uggen 2004)). The United States has withdrawn from efforts to promote racial integration in schools ((Orfield and Lee 2004)); the upward mobility of Latino immigrants and their descendents may be stalled by the third generation (ALBA PAPER). Policies do not track public opinion in any simple sense, but the United States' 
mixed record with regard to egalitarian policies mirrors whites', and even blacks', ambivalence about equalization.

Pondering the context in which Tocqueville wrote provides another angle on the United States' mixed record of equalization. Tocqueville, along with almost all political actors in the 1830s, excluded African Americans and women of all races from his mental map of democratic citizens; given those exclusions, he was perhaps more right than wrong about the desire for equality. People find it relatively easy to promote equality for those whom they consider to be like themselves, at least compared with people outside their group. Enfranchised white men were able to bring propertyless white men into their political world with relatively little controversy over about a decade in the $1820 \mathrm{~s}$ ((Peterson 1966)). It took almost another century and much struggle for them to admit white women ((Banaszak 1996)). It required another half-century to admit non-European immigrants to the franchise - and still more decades and great violence including deaths to give black Americans a meaningful role in the political system. Blacks' ambivalence about equality similarly revolves around their anxiety about groups outside their own: are immigrants, women of other races, poor Anglos, gays, and other people of color to be understood as mostly like themselves, therefore also subject to discrimination and economic exploitation ((Guinier and Torres 2002)), or are those groups mostly like white men, therefore primed to join the advantaged discriminators as soon as they are able to do so ${ }^{11}$

A passion for equality turns out to be hard to sustain, not at all an "irresistible revolution advancing ... over every obstacle," especially for people who seem to be unlike oneself. It is easier to remain blind to injustices that affect others; it is easier to accept an inegalitarian policy in order to promote some other cherished value; it is easier to exclude people outside one's own group from those to whom equality must extend, and then to define one's own group relatively narrowly. Blacks in the United States (and Latinos, to a degree) resist these choices more than whites do, but all groups are subject to the same pressures and sometimes express preferences that sustain rather than interrupt oppression.

\section{A Crucial Caveat}

I have written so far as though the promotion of one's group's interests is a fairly straightforward political impulse. People define their group as people like them in some crucial way, and they seek justice, here defined mainly as greater equality, for that group. They perceive those outside the group more dimly and care less about whether justice is done to them, or they sometimes perceive outsiders as threats or even enemies, who must be stalled or defeated in order for justice to be done. This is a common political model, used to explain a wide array of contests from elections to wars, and it has strong empirical support.

11 In the 2000 NCCJ survey, 58 percent of blacks agreed that blacks suffer from a lot of discrimination, but only 31 percent said the same about Hispanics , 36 percent about immigrants, and 18 percent or lower for Asians and whites. Latinos, however, saw as much discrimination against Latinos as against blacks (35 percent for blacks, 37 percent for Hispanics), and even more against immigrants (52 percent perceived great discrimination against immigrants). 
It is too simple, however, in a variety of ways. Who is defined in or outside one's group -- "how wide the circle of the we?" ((Hollinger 1993))-- is itself socially, politically, and psychologically contested and constructed. Neither racial nor any other kind of identity is a given. How justice should be defined -- as greater material equality and more open social and moral norms, as I have done here, or as reward for merit, procedural fairness, or some other way -- is just as deeply contested. Perhaps most importantly, the underlying assumption that group interests provide the most important motivating force behind one's desire for justice is contestable. People sometimes respond differently to appeals for justice depending on their social, historical, demographic or political context (for a good example, see (Taylor 2000)). They sometimes hold immutable values that they apply to all people and circumstances, whether that value be racial or class domination or the equal right to have one's needs met. They sometimes hold other motives -- pacifism, revenge, loyalty, religious salvation, narrow self-interest -- that supercede the pursuit of justice, however defined.

This paper -- or a lifetime! -- cannot examine the full array of social constructions, motivations, beliefs, and contexts that explain why Tocqueville was right to point towards the impulse toward equality held by residents of the United States but wrong to see it as an "irresistible revolution advancing century by century over every obstacle." I turn instead to the only slightly less daunting task of considering the implications for political action of the patterns I have laid out.

\section{Where Do We Go From Here?}

Let me assume that readers share my view that greater material equality among all residents of the United States and more open social and moral norms would promote justice and significantly reduce oppression. Even after making that rather heroic assumption, each step of the above analysis is just a beginning in helping us to shape political action.

Consider first the list of moments in which our nation moved closer to equality. What were the circumstances under which these changes were promulgated? Who were the crucial actors; what affected the timing of their success; what kinds of proposals succeeded despite the failure of others? We can start by noting that, setting aside the Civil War as perhaps sui generis (and not a model which we would wish to emulate), most of this set of reforms came about through laws created by political elites. It would be valuable to know what combination of popular protest, fear of threat, economic incentives, foreign policy considerations, political maneuvering, and moral commitments motivated elites to act in these ways.

Note, second, that the substantive character of proposed reforms themselves affect whether laws get passed and then implemented. Efforts to promote greater equality have more often succeeded in the United States if they enjoyed two characteristics. They must be intrinsically easy to promulgate and implement. That is, the reform offsets market distortions caused by prior exclusion, the reform requires few steps between intent and outcome; the reform diffuses costs widely, or the reform generates visible gains for important political constituencies. In addition, their means of promulgation gives advantages to certain reform proposals: a successful reform is closely identified with powerful political actors, it can build on strong institutional structures already in place, it can allow some actors to impose change and its costs on others with less power, it is 
addressed to hierarchical organizations, or it is intrinsic to the core mission of the implementing agency (for more detail, see Hochschild 1998)).

These characteristics of successful reforms can be linked in the following way to my earlier discussion about when people seek greater equality: some reform efforts enable people to expand the definition of who is to be included in their group and therefore who ought to obtain justice. Mandated desegregation of public accommodations in the 1950s offset a market distortion, while enabling restaurant and hotel owners to expand their definition of a legitimate customer to anyone with the right amount of money. Mandates to permit homosexual marriage in Massachusetts in 2003 built on a strong institutional structure already in place while enabling citizens to give gays and lesbians the same rights and moral standing that they had already granted heterosexual couples. Legalizing the right to unionize in the 1930s gave a visible gain to a strong political constituency of the Democratic party, diffused payment for increased labor costs widely across the society, and enabled citizens to see organized labor like any other organized group, with the same economic and moral rights.

But this is just a start; we need a clearer understanding of when, how, and why the United States has sometimes promulgated equality over other values, or expanded the group of people who could make legitimate claims on justice. Figuring out how political actors at some point in the past connected with or changed public opinion about the meaning of justice, the groups entitled to justice, or the priority of justice will help other political actors in the future.

The survey data showing how people combine belief in a principle with disavowal of plausible measures for pursuing it can imply two distinct political strategies. The combination may cut people off from their own impetus to respond to injustice, as in "I truly believe that all Americans should be treated fairly and equally; I simply think that this mechanism for promoting justice is misguided or unnecessary." The task in that case for political actors looking for allies is either to show that the mechanism under discussion is in fact essential for promoting justice, or to find an alternative mechanism that fits more clearly into the person's underlying commitment to justice. That leads us back to the discussion above, of designing policy proposals in a way that gives them a good chance of promulgation and implementation.

Alternatively, the disjunction between principle and policy views may make people sufficiently uneasy that they can be mobilized into a broader campaign for promoting greater justice across the board. That is the classic claim of Gunnar Myrdal's American dilemma: "the ever-raging conflict between... the valuations preserved on the general plane... [of] the 'American Creed'... and... the valuations on specific planes of individual and group living" ((Myrdal 1944): xlvii). Myrdal was a (strategic?) optimist but no Pollyanna; whites are slowly changing their ways, he concluded, but "if American wants to make the ... choice [i.e., admit Negroes into full citizenship] she cannot wait and see. She has to do something big, and do it soon" (ibid., p. 1022). Martin Luther King Jr. used roughly the same strategy - seeking to show fellow blacks and then all Americans that their democratic, liberal, and Christian principles were irredeemably violated by the laws and practices of segregation. Malcolm X did the same within the black community and Betty Friedan among women - demanding that people who already perceived injustice and inequality against other members of their group come out of their shells and get politically engaged to achieve what they knew was right. 
Finally, then, let us consider possible coalitions for promoting reform. There are several kinds. A coalition may stem from and reinforce identity politics. In this model, activist groups form among people motivated to take political action by a strong commitment to their own group; later, they become willing to work with other groups in order to foster the interests of their own. That is the impulse behind Latino or Asian panethnic movements, the Leadership Conference for Civil Rights, or Lani Guinier and Gerald Torres's "progressive democratic movement led by people of color but joined by others" ((Guinier and Torres 2002)). Sometimes these coalitions expand the boundaries around what is seen as the core group: reading the same demographic projections as every one else, labor unions have begun to woo immigrant workers by expressing concern about immigrant rights and support for amnesty for illegal immigrant workers.

Or a reform coalition may be much more instrumental; the phrase "politics makes strange bedfellows" is not a cliché for nothing. In this case, activists are pragmatic and instrumental, finding allies wherever they can so that small groups can win a victory in a political system that rewards voting majorities and substantial resources. Such activists do not expect alliances to persist; longevity will depend on whether interests consistently coincide and whether groups can develop effective working relationships. Thus black inner-city ministers have provided the staunchest support for President George W. Bush's initiative to expand faith-based social services, and self-identified black nationalists have worked with white Republican mayors and conservative foundations to create publiclyfunded school voucher programs.

A third type of coalition is driven by an ideological commitment that cuts across group identities and has much deeper personal meaning and longer political life than a pragmatic coalition of interests. Thus visionaries on the left in the United States have long promoted interracial working-class coalitions in the name of promoting justice and ending oppression, while visionaries on the right have for an equally long time promoted intergroup coalitions in the name of traditional morality and fundamentalist religious commitments. In contrast, finally, some coalitions may be almost entirely contextual -neighborhood associations are a key example. In this case, ideology and group identities matter relatively little, whereas the content of very particular policy proposals and sheer physical proximity provide the motivating force for action. Such coalitions may not be very glamorous, but they can have a big impact on ameliorating quotidian injustices such as the lack of street lights, filthy vacant lots or playgrounds, or an ineffective local school principal ((Berry, Portney and Thomson 1993); (Warren 2001)).

Judging what kind of coalition to foster depends on a mix of considerations: the issue at hand, the demographic and political context, the intensity and extensiveness of group identities, the availability of a powerful ideology or principle on which to draw, the position of political elites, the proclivities of leaders, and more. There are no simple, clear rules -- or even complicated, clear rules. Public opinion surveys show that the elements are sometimes at hand for political mobilization, but they also show the many points of blockage. No nation or society will ever fully interrupt oppression, and justice will never be fully sustained. Nevertheless, residents of the United States believe in equality and seek it (especially for members of their own group), and on occasion institutions, laws, and practices can be made to respond. Tocqueville was not completely wrong, and that is a sufficient basis for continued efforts. 
ACKNOWLDEGEMENTS: I thank participants in the 2004 conference on "Interrupting Oppression and Sustaining Justice" at Columbia University Teachers College, especially Morton Deutsch and Jack Snyder, for provocative and helpful comments. Thanks also to participants in the 2003 conference at Duke University sponsored by the Gerst Program in Political, Economic, and Humanistic Studies on "America's Ambivalent Egalitarianism: Facts and Perceptions," especially Stanley Renshon and Nan Keohane, for their comments on an earlier draft. Finally, my grateful thanks go to the Guggenheim Foundation, Radcliffe Institute for Advanced Study, and Weatherhead Center for International Affairs at Harvard University for financial and intellectual support.

\section{References}

Associated Press (2003). Poll. February 28-March 4.

Banaszak, L. A. (1996). Why Movements Succeed or Fail: Opportunity, Culture, and the Struggle for Woman Suffrage. Princeton, NJ: Princeton University Press.

Berry, J., K. Portney, and K. Thomson (1993). The Rebirth of Urban Democracy. Washington D.C.: Brookings Institution Press.

Bureau of Justice Statistics (2001). Sourcebook of Criminal Justice Statistics. Washington D.C.: Department of Justice.

--- (2004). Sourcebook of Criminal Justice Statistics 2002. Washington D.C.: Department of Justice,

Charles F. Kettering Foundation (1971). Attitudes Toward the Public Schools. April 2326 Dayton Ohio: Kettering Foundation.

CNN/ U.S.A. Today (1994). Gallup, CNN, U.S.A. Today Poll. April 22-24.

--- (1999). Gallup, CNN, U.S.A. Today Poll. July 16-18.

Davis, J. (1997). The GSS -- Capturing American Attitude Change. Public Perspective. 8 (2): $31-34$.

Davis, J., T. Smith, and P. Marsden (2001). General Social Surveys, 1972-2000:

Cumulative Codebook. Chicago IL: National Opinion Research Center.

Dawson, M. and R. Popoff (2004). Reparations: Justice and Greed in Black and White. Du Bois Review. 1 (1): 47-91.

de Tocqueville, A. (1966 (1848)). Democracy in America. New York: Harper \& Row.

Elam, S., Ed. (1989). The Gallup/Phi Delta Kappa Polls of Attitudes Toward the Public Schools, 1969-88. Bloomington IN: Phi Delta Kappa Educational Foundation.

Fox News (2001). Fox News, Opinion Dynamics Poll. March 28-29.

Gallup Organization (1973). Gallup Poll -- AIPO. Gallup Poll Monthly. August 3-6.

--- (1975). Gallup Poll -- AIPO. Gallup Poll Monthly. September 12-15.

--- (1997). The Gallup Poll Social Audit on Black/White Relations in the United States. Princeton NJ:

--- (2003). Blacks Lag Behind Whites in Life Satisfaction. www.gallup.com/poll/releases/pr040119.asp. 
Guinier, L. and G. Torres (2002). The Miner's Canary: Enlisting Race, Resisting Power, Transforming Democracy. Cambridge MA: Harvard University Press.

Hamilton, D. and C. Hamilton (1997). The Dual Agenda: Race and Social Welfare Policies of Civil Rights Organizations. New York: Columbia University Press.

Harris, L., and Associates, (1970). Harris Survey. March New York.

--- (1978). San Bernardino, California Community Survey. March New York.

Hochschild, J. (1981). What's Fair? American Beliefs about Distributive Justice. Cambridge MA: Harvard University Press.

--- (1984). The New American Dilemma: Liberal Democracy and School Desegregation. New Haven CT: Yale University Press.

--- (1995). Facing Up to the American Dream: Race, Class, and the Soul of the Nation. Princeton NJ: Princeton University Press.

--- (1998). You Win Some, You Lose Some...Explaining the Pattern of Success and Failure in the Second Reconstruction. in Keller, M. and R. S. Melnick (ed.), Taking Stock: Policy and Governance in the Twentieth Century. New York: Oxford University Press.

Hochschild, J. and M. Herk (1990). 'Yes, but...': Principles and Caveats in American Racial Attitudes. in Chapman, J. and A. Wertheimer (ed.), Nomos XXXII: Majorities and Minorities. New York: New York University Press. pp. 308-35.

Hollinger, D. (1993). How Wide the Circle of the "We"? American Intellectuals and the Problem of the Ethnos Since World War II. American Historical Review. 98 (2): 317-37.

Hurwitz, J. and M. Peffley (2001). Racial Polarization on Criminal Justice Issues: Sources and Political Consequences of Fairness Judgements. American Political Science Association, San Francisco CA.

Jennelle, B. (2001). Flying in the Face of Racism. Harvard Crimson, November 6. Johnson, D. (2002). Justice or 'Just Us?' Perceived Racial Bias in the Criminal Justice System. Cambridge MA: Harvard University, Department of Sociology,

Jost, J., et al. (2003). Social Inequality and the Reduction of Ideological Dissonance on Behalf of the System: Evidence of Enhanced System Justification among the Disadvantaged. European Journal of Social Psychology. 33 (1): 13-36.

Kahlenberg, R. (2001). The Fall and Rise of School Segregation. American Prospect, 4143.

Manza, J. and C. Uggen (2004). Punishment and Democracy: Disfranchisement of Nonincarcerated Felons in the United States. Perspectives on Politics. 2 (3): 491506

McPherson, J. (1997). For Cause and Comrades: Why Men Fought in the Civil War. New York: Oxford University Press.

Mills, C. (1997). The Racial Contract. Ithaca NY: Cornell University Press.

Myrdal, G. (1944). An American Dilemma. New York: Harper \& Brothers.

NAACP Legal Defense and Educational Fund (1989). The Unfinished Agenda on Race in America, Vol. 1. New York:

National Conference for Community and Justice (2000). Taking America's Pulse II: A Survey of Intergroup Relations. New York: National Conference for Community and Justice,

NBC News/ Wall Street Journal (2002). Poll. July 19-21. 
Newsweek (1997). Princeton Survey Research Associates, Newsweek Poll. June 19-20.

Nozick, R. (1974). Anarchy, State and Utopia. New York: Harper and Row.

Orfield, G. and C. Lee (2004). Brown at 50: King's Dream or Plessy's Nightmare? Cambridge MA: Harvard University, Civil Rights Project,

Pateman, C. (1988). The Sexual Contract. Stanford, CA: Stanford University Press.

Peterson, M. (1966). Democracy, Liberty and Property; The State Constitutional Conventions of the 1820's. Indianapolis, IN: Bobbs-Merrill Co.

Pole, J. R. (1993). The Pursuit of Equality in American History. Berkeley CA: University of California Press.

Rae, D. (1988). Knowing Power. in Shapiro, I. and G. Reeher (ed.), Power, Inequality, and Democratic Politics. Boulder CO: Westview Press. pp. 17-49.

Rae, D., et al. (1981). Equalities. Cambridge MA: Harvard University Press.

Rainwater, L. and T. Smeeding (2003). Poor Kids in a Rich Country: America's Children in Comparative Perspective. New York: Russell Sage Foundation.

Rawls, J. (1999). A Theory of Justice. Cambridge MA: Belknap Press of Harvard University Press.

Schaar, J. (1964). Some Ways of Thinking about Equality. Journal of Politics. 26 (4): $867-95$.

Schuman, H., et al. (1997). Racial Attitudes in America: Trends and Interpretations. Cambridge MA: Harvard University Press.

Smith, R. (1997). Civic Ideals: Conflicting Visions of Citizenship in U.S. History. New Haven CT: Yale University Press.

Taylor, M. (2000). The Significance of Racial Context. in Sears, D., J. Sidanius, and L. Bobo (ed.), Racialized Politics: The Debate about Racism in America. Chicago: University of Chicago Press. pp. 118-36.

Time, C.N.N., and Harris Interactive (2003). Poll. February 19-20.

Warren, M. (2001). Dry Bones Rattling: Community Building to Revitalize American Democracy. Princeton NJ: Princeton University Press.

Wortley, S., J. Hagan, and R. Macmillan (1997). Just Des(s)erts? The Racial Polarization of Perceptions of Criminal Justice. Law \& Society Review. 31 (4): 637-76. 